\title{
First Subject Screened Date Time
}

National Cancer Institute

\section{Source}

National Cancer Institute. First Subject Screened Date Time. NCI Thesaurus. Code C142560.

The date and time when the first individual is screened for a clinical study. 